\title{
Spatial and temporal differences in the fish assemblage structure in a subtropical estuary
}

\author{
André P. Cattani ${ }^{1}$, Gisela C. Ribeiro ${ }^{2}$, Mauricio Hostim-Silva ${ }^{3}$, Marcelo Soeth ${ }^{1}$ \\ Leandro Clezar ${ }^{2}$, Olímpio R. Cardoso ${ }^{1,4}$, Helen A. Pichler ${ }^{5} \&$ Henry L. Spach ${ }^{1}$ \\ ${ }^{1}$ Universidade Federal do Paraná, Centro de Estudos do Mar, Pontal do Paraná, Brasil \\ ${ }^{2}$ Universidade Federal de Santa Catarina, Núcleo de Estudos do Mar, Florianópolis, Brasil \\ ${ }^{3}$ Universidade Federal do Espírito Santo, Pós-graduação em Biodiversidade Tropical, Vitória, Brasil \\ ${ }^{4}$ Universidade Federal do Paraná, Pós-graduação em Zoologia, Curitiba, Brasil \\ ${ }^{5}$ Universidade Federal do Espírito Santo, Depto. de Ciências Agrárias e Biológicas, São Mateus, Brasil \\ Corresponding author: Olímpio R. Cardoso (rafael.bioufrgs@ gmail.com)
}

\begin{abstract}
A large number of fish species use the mangrove mainly due to food availability and protection against predators. The knowledge of temporal and spatial dynamics of ichthyofauna allows us to identify patterns of occupation of this ecosystem and to support the assessment and preservation of local biodiversity. In this sense, samplings were conducted in 1988 at five areas of the Itacorubi River estuary, Santa Catarina Island. A total of 3,883 specimens were collected, distributed in 21 families and 41 species with the predominance of Cetengraulis edentulus, Mugil liza, Mugil curema, Genidens genidens, Mugil gaimardianus, Eucinostomus gula, Micropogonias furnieri, Pomatomus saltatrix and Sphoeroides testudineus. On average, abundances differed between seasons and sampled areas. Differences were detected between the fish faunas of fall and winter compared to summer and spring and between sampling sites. This study identified a fish assemblage in the mangrove of the Itacorubi River with a similar structure to other estuaries of southern Brazil.
\end{abstract}

Keywords: fish; biodiversity; mangrove; Santa Catarina Island; southern Brazil

\section{INTRODUCTION}

In tropical and subtropical coastal areas, mangroves are one of the most endangered and important biological ecosystems, offering various environmental and economic services, such as coast protection, sediment retention, carbon sequestration, assimilation and transformation of nutrients, recreation and products of plant and animal origin (Rönnbäck et al., 1999; Dahdouh-Guebas et al., 2005; Blaber, 2007; Hussan \& Bardolla, 2008). In mangroves, we can find a high diversity of marine and terrestrial species of fish, crustaceans, birds, reptiles and mammals (Alongi, 2002).

Compared to the nearby sandy and muddy plains, mangroves contain a large number of fish and species, especially at the juvenile stage (Kathiresan \& Bringhan, 2001; Laegdsgaard \& Johnson, 2001; Faunce \& Serafy, 2006). The most intense use of this ecosystem by fish would be related to the abundance of food due to high productivity and associated benthic fauna (Kathiresan \& Bringhan, 2001; Laedsgaard \& Johnson, 2001) and the availability of protection against predators, mainly due to the structural complexity, shade, turbidity and shallow local depth (Cyrus \& Blaber, 1987; Rönnbäck et al., 1999; Ellis \& Bell, 2004; Verweij et al., 2006).

In addition to the influence of environmental factors on the spatial and temporal variations of the fish fauna in mangroves (Huxham et al., 2004; Pittman et al., 2004; Lugendo et al., 2007; Nagelkerken \& Faunce, 2007), latitude, coastal configuration and the ecological processes can also contribute to these variations (Verweij et al., 2006; Rypel et al., 2007; Guilstrom et al., 2008). Furthermore, more than 50 percent of the world's population lives within the $50 \mathrm{~km}$ coastline, with the coastal community, especially in underdeveloped countries, using mangroves for livelihood, causing, among other things, disappearance at alarming rates of mangrove areas because of activities such as aquaculture, timber production, urbanization, tourism

Corresponding editor: Guido Plaza 
and pollution (Valiela et al., 2001; Alongi, 2002; Duke et al., 2007). Changes in mangroves may affect the structure of fish assemblages by interfering with species that use the area during their life cycle (Williamson et al., 1994; Huxham et al., 2004).

This study surveyed and evaluated seasonal and spatial changes of the fish community in a subtropical southern mangrove in the South American continent, specifically in Itacorubi River estuary, Santa Catarina Island, Brazil. This information is needed to understand how fish use this ecosystem and the strategies that can be used to maintain local biodiversity.

\section{MATERIALS AND METHODS}

\section{Study area}

In the western margin of Santa Catarina Island and to the south of the northern bay, there is the Itacorubi mangrove $\left(27^{\circ} 34^{\prime} 14^{\prime \prime}-27^{\circ} 35^{\prime} 31^{\prime \prime} \mathrm{S}, 48^{\circ} 30^{\prime} 07^{\prime \prime}-48^{\circ} 31^{\prime} 33^{\prime \prime} \mathrm{W}\right)$ (Fig. 1), with an area of $1.42 \mathrm{~km}^{2}$ (Soriano-Sierra, 1993), perimeter of $5.8 \mathrm{~km}$, corresponding to $0.32 \%$ of the municipality of Florianópolis (Panitz, 1986). In this estuary, predominates fine sediments, mainly silt and vegetation composed of Avicennia schaueriana, and to a lesser extent Laguncularia racemosa, Rhizophora mangle and Spartina alterniflora (Soariano-Sierra, 1997). A remarkable feature of this mangrove is the high degree of anthropization through organic and chemical pollution due to its location close to the urban network and the past use of this site to deposit municipal waste, including domestic and hospital waste (Soriano-Sierra et al., 1998).

The region has a humid subtropical climate, and rainfall is distributed throughout the year, with winds predominating from the north/northeast quadrant and maximum average temperatures in February and minimum in June (Dutra, 1998; MMA, 2004a). In the region, the tidal regime is semi-diurnal, with a maximum amplitude of $0.63 \mathrm{~m}$ inside the Itacorubi Estuary (Soriano-Sierra, 1997).

\section{Sampling}

In 1988, monthly samplings were carried out at five distinct areas: 1-mouth near the northern bay, 2confluence of the rivers, 3 and 4-Itacorubi River, 5Sertão River (Fig 1). In each area and each month, 30 throws were performed with the aid of cast nets with 10 and $20 \mathrm{~mm}$ mesh between opposing knots, with 15 throws for each net.

In the field, collected fish were packed in Styrofoam box with ice and transported to the laboratory. Fish were identified, measured (TL mm) and weighed (g) and classified according to the trophic guilds, using the estuary and depth preference based on regional literature (Passos et al., 2013; Pichler et al., 2015).

\section{Statistical analysis}

The following simple linear model was used to test the spatial and temporal fish assemblage variation in Itacorubi mangrove: $\mathrm{Y}=\mu+\mathrm{Es}+\mathrm{Ar}+\mathrm{Es} \times \mathrm{Ar}+e$, where $Y$ : dependent variable; $\mu$ : mean; Es: season of the year, Ar: area; e: error. The factors seasons of the year (summer: December, January, February; fall: March, April, May; winter: June, July, August; spring: September, October, November) and areas (1, 2, 3, 4 and 5) were considered fixed and orthogonal.

In general, to test the hypothesis of spatial and temporal differences in fish abundance, a permutational multivariate analysis of variance (Permanova) was applied (Anderson et al., 2008). Permanova is a univariate or multivariate analysis of variance, which uses permutation procedures based on any measure of similarity. The advantage of this type of analysis is the absence of assumptions, as is the case of normality. Thus, it is a non-parametric analysis that allows the use of fixed or random factors related to orthogonally (crossed) or nested in hypothetical descriptive or experimental models (Anderson et al., 2008).

When the null hypothesis was rejected by Permanova, a pairwise Permanova was applied for $a$ posteriori comparisons between factors that had significant differences $(P<0.05)$, which is a similar test to a post-hoc analysis. In order to visualize the differences found in Permanova, we performed the canonical analysis of principal coordinates (CAP), which generates the graphical clusters through permutation (Anderson et al., 2008). Within the CAP analysis, the Spearman correlation at the 0.5 level was used to determine which species (vectors) were responsible for the clusters.

\section{RESULTS}

\section{Fish assemblage}

A total of 3,883 individuals was collected, belonging to 21 families and 41 species (Table 1). The families that presented the highest species richness were Gerreidae (5 species), Mugilidae and Sciaenidae (4 each), Ariidae and Engraulidae (3 each), and Clupeidae, Gobiidae and Paralichthyidae (2 each) (Table 1). The other families had the occurrence of only one species.

In descending order, Cetengraulis edentulus, Mugil liza, Mugil curema, Genidens genidens, Mugil gaimardianus, Eucinostomus gula, Micropogonias furnieri, Pomatomus saltatrix, and Sphoeroides testudineus represented $90 \%$ of the catch in number; the 


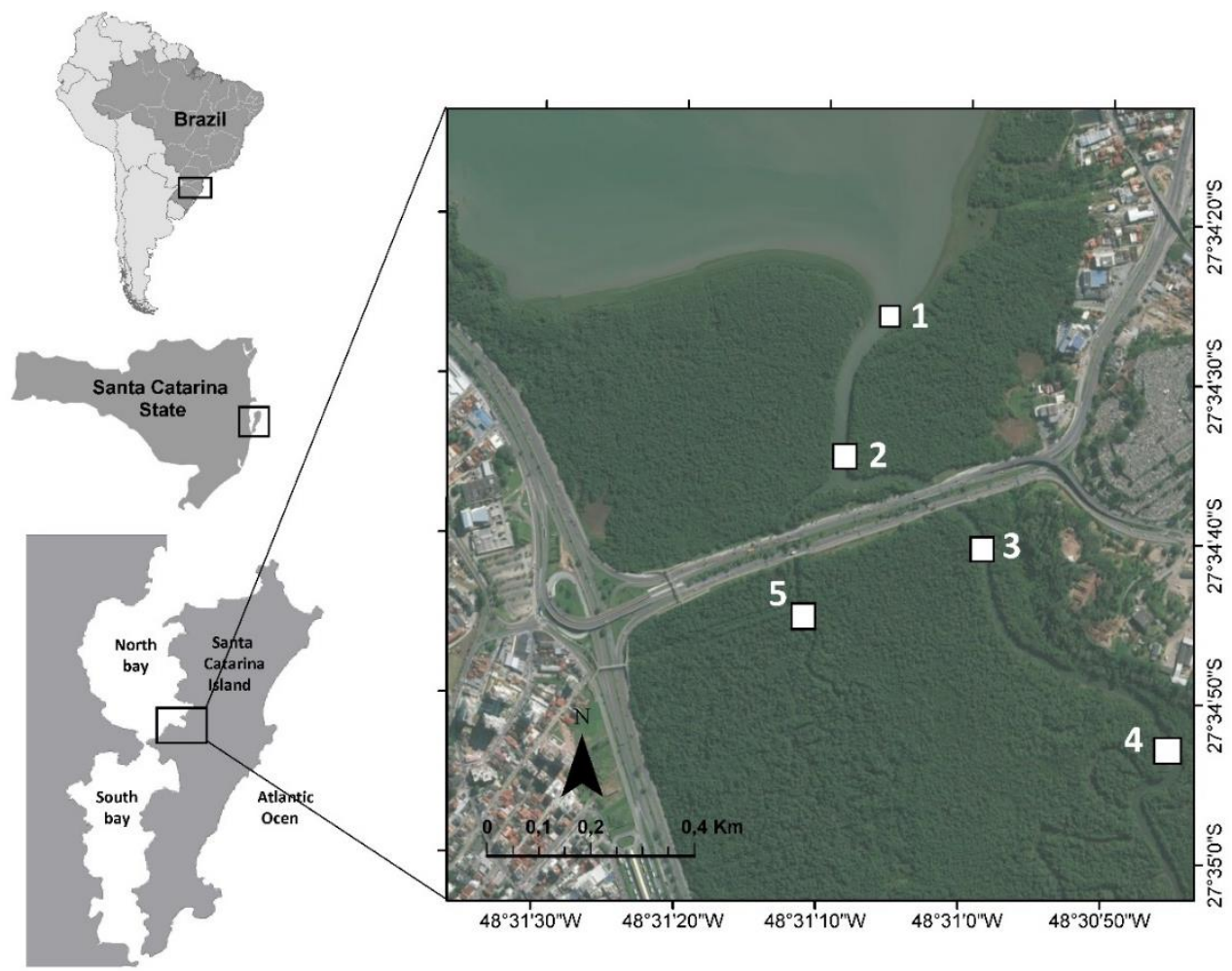

Figure 1. Map of the study area, detailing the five areas sampled in the Itacorubi mangrove, Santa Catarina Island, State of Santa Catarina, Brazil.

catch of C. edentulus accounted for approximately $65 \%$ of the total. Each of the other species contributed less than $1 \%$ of the total catch (Table 1). The total catch weight corresponded to 44,903.05 g (Table 1), with $M$. liza, C. edentulus, M. curema, M. furnieri, G. genidens, Cynoscion leiarchus, $S$. testudineus, P. saltatrix, M. gaimardianus and E. gula corresponding, in descending order, to approximately $91 \%$ of this total (Table 1). The catch of M. liza and C. edentulus accounted for approximately $70 \%$ of the total catch weight.

The broader total length range occurred for $M$. liza (316 mm), G. genidens (224 mm), Cathorops spixii (200 mm), S. testudineus (191 mm), Strongylura marina $(155 \mathrm{~mm})$, C. edentulus $(148 \mathrm{~mm}), M$. furnieri $(144 \mathrm{~mm})$ and $C$. leiarchus $(139 \mathrm{~mm})$, with predominance in the area of transient and demersal species, with residents and transients mostly demersal. Most species, considering their feeding habit, are zoobenthivorous, with a numerical predominance of zooplanktivorous species followed by detritivorous species (Table 1).

Comparing the values of abundance between seasons and areas, Permanova detected significant differences $(P<0.05)$ between the seasons and areas, and there were no significant differences in the interac- tion between the factors (Table 2). In the paired comparisons (Permanova pairwise test) between seasons, only between summer and fall and between summer and spring, differences between means were not significant (Table 3). In the paired comparisons between areas, only the differences between areas 1 and 2, 1 and 3 and between 2 and 3 were not statistically significant (Table 4).

The highest mean abundance occurred in the fall in areas 2 (mean \pm standard deviation, $221.82 \pm 210.54$ ) and $4(92.79 \pm 68.7)$, followed by winter in area 4 $(81.49 \pm 65.67)$, summer in areas $4(27.21 \pm 27.74)$ and $3(16.62 \pm 18.85)$ and winter in area $2(16.23 \pm 14.68)$ (Fig. 2). The lowest values occurred in the spring in area $1(3.18 \pm 2.2)$, in the summer in areas $5(3.07 \pm$ 2.5) and 1 (2.64 \pm 1.89$)$, in winter in area $5(2.15 \pm$ $1.28)$, spring in area $5(1.67 \pm 0.98)$ and fall in area 5 $(1.42 \pm 0.67)$ (Fig. 2).

In the canonical analysis of principal coordinates (CAP), with the season of the year as factor, we verified a separation of the samples of the fall and winter more to the right and bottom of the graph and the summer and spring samples to the left and top of the graph (Fig. 3). High abundances of $C$. leiarchus, M. furnieri and $C$. edentulus in the summer and spring, as well as the predo- 
Table 1. List of species, number of individuals (n), weight (W), mean, minimum and maximum total length (TL), trophic guild (TG) (ZP: zooplanktivorous, DV: detritivorous, PV: piscivorous, ZB: zoobenthivorous, OP: opportunistic), guild of use of the estuary (GU) (R : resident, T: transient) and depth preference (DP) (P: pelagic, D: demersal, BP: benthopelagic) of fish caught in 1988 in the Itacorubi mangrove, Santa Catarina Island. Global conservation status, according to IUCN (2019): data deficient ${ }^{1}$, least concern ${ }^{2}$, vulnerable ${ }^{3}$, endangered ${ }^{4}$. National conservation status according to Ministry of the Environment (MMA) (2004b): $\uparrow$ : endangered, $\uparrow \dagger$ : overexploited.

\begin{tabular}{|c|c|c|c|c|c|c|c|c|}
\hline Families/Species & $\mathrm{n}$ & $\begin{array}{l}\mathrm{W} \\
(\mathrm{g})\end{array}$ & $\begin{array}{c}\text { Mean TL } \\
(\mathrm{mm})\end{array}$ & $\begin{array}{l}\text { Min-Max TL } \\
(\mathrm{mm})\end{array}$ & TG & GU & DP & $\begin{array}{l}\text { Economic } \\
\text { importance }\end{array}$ \\
\hline $\begin{array}{l}\text { Achiridae } \\
\text { Achirus lineatus }{ }^{2} \\
\text { Ariidae }\end{array}$ & 3 & 13.17 & 58 & $46-69$ & $\mathrm{ZB}$ & $\mathrm{R}$ & $\mathrm{D}$ & Yes \\
\hline Cathorops spixii & 7 & 373.47 & 161.57 & $81-281$ & ZB & $\mathrm{R}$ & $\mathrm{D}$ & Yes \\
\hline Genidens barbus ${ }^{4}$ & 38 & 579.7 & 114.42 & $77-172$ & $\mathrm{ZB}$ & $\mathrm{T}$ & $\mathrm{D}$ & Yes \\
\hline $\begin{array}{l}\text { Genidens genidens }{ }^{2} \dagger \\
\text { Atherinopsidae }\end{array}$ & 108 & 1504 & 101.22 & $61-285$ & $\mathrm{ZB}$ & $\mathrm{T}$ & $\mathrm{D}$ & Yes \\
\hline $\begin{array}{l}\text { Atherinella brasiliensis }{ }^{2} \\
\text { Belonidae }\end{array}$ & 15 & 70.92 & 82.13 & $44-105$ & $\mathrm{OP}$ & $\mathrm{R}$ & $\mathrm{P}$ & Yes \\
\hline $\begin{array}{l}\text { Strongylura marina }{ }^{2} \\
\text { Carangidae }\end{array}$ & 7 & 91.62 & 215.29 & $153-308$ & PV & $\mathrm{T}$ & $\mathrm{P}$ & Yes \\
\hline Oligoplites palometa ${ }^{2}$ & 33 & 191.21 & 80.70 & $33-130$ & PV & $\mathrm{T}$ & $\mathrm{P}$ & Yes \\
\hline Oligoplites saliens $^{2}$ & 3 & 3.73 & 55 & $54-56$ & $\mathrm{ZP}$ & $\mathrm{T}$ & $\mathrm{P}$ & Yes \\
\hline Oligoplites saurus ${ }^{2}$ & 3 & 11.06 & 79.33 & $74-86$ & PV & $\mathrm{T}$ & $\mathrm{P}$ & Yes \\
\hline $\begin{array}{l}\text { Selene vomer } \\
\text { Centropomidae }\end{array}$ & 1 & 6.26 & 80 & 80 & $\mathrm{ZB}$ & $\mathrm{T}$ & $\mathrm{D}$ & Yes \\
\hline $\begin{array}{l}\text { Centropomus parallelus }{ }^{2} \\
\text { Cichlidae }\end{array}$ & 4 & 49.63 & 106.5 & $86-139$ & $\mathrm{ZB}$ & $\mathrm{R}$ & $\mathrm{D}$ & Yes \\
\hline $\begin{array}{l}\text { Geophagus brasiliensis } \\
\text { Clupeidae }\end{array}$ & 9 & 385.9 & 124.89 & $103-166$ & $\mathrm{ZB}$ & $\mathrm{T}$ & $\mathrm{P}$ & Yes \\
\hline Harengula clupeola ${ }^{2}$ & 38 & 167.4 & 75.21 & $64-99$ & $\mathrm{ZP}$ & $\mathrm{T}$ & $\mathrm{P}$ & Yes \\
\hline $\begin{array}{l}\text { Sardinella brasiliensis } \dagger \\
\text { Cynoglossidae }\end{array}$ & 1 & 3.33 & 69 & $69-69$ & $\mathrm{ZP}$ & $\mathrm{T}$ & $\mathrm{P}$ & Yes \\
\hline $\begin{array}{l}\text { Symphurus tessellatus }{ }^{2} \\
\text { Elopidae }\end{array}$ & 18 & 95.18 & 90 & $73-126$ & $\mathrm{ZB}$ & $\mathrm{T}$ & $\mathrm{D}$ & Yes \\
\hline $\begin{array}{l}\text { Elops saurus }^{2} \\
\text { Engraulidae }\end{array}$ & 5 & 198.15 & 192 & $173-208$ & $\mathrm{PV}$ & $\mathrm{T}$ & $\mathrm{P}$ & Yes \\
\hline Anchoa januaria & 24 & 30.08 & 56.42 & $43-70$ & $\mathrm{ZP}$ & $\mathrm{R}$ & $\mathrm{P}$ & Not \\
\hline Cetengraulis edentulus ${ }^{2}$ & 2579 & 12192 & 81.28 & $16-164$ & $\mathrm{ZP}$ & $\mathrm{T}$ & $\mathrm{P}$ & Yes \\
\hline $\begin{array}{l}\text { Lycengraulis grossidens }{ }^{2} \\
\text { Gerreidae }\end{array}$ & 26 & 457.25 & 132.15 & $102-169$ & $\mathrm{ZP}$ & $\mathrm{T}$ & $\mathrm{P}$ & Yes \\
\hline Diapterus rhombeus ${ }^{2}$ & 4 & 12.48 & 62.5 & $52-77$ & $\mathrm{ZB}$ & $\mathrm{T}$ & $\mathrm{D}$ & Yes \\
\hline Eucinostomus argenteus ${ }^{2}$ & 38 & 263.91 & 79.97 & $62-111$ & $\mathrm{ZB}$ & $\mathrm{T}$ & $\mathrm{D}$ & Yes \\
\hline Eucinostomus gula ${ }^{2}$ & 84 & 581.64 & 79.5 & $48-115$ & $\mathrm{ZB}$ & $\mathrm{T}$ & $\mathrm{D}$ & Yes \\
\hline Eucinostomus melanopterus ${ }^{2}$ & 7 & 97.01 & 100.43 & $57-153$ & $\mathrm{ZB}$ & $\mathrm{T}$ & $\mathrm{D}$ & Yes \\
\hline Eucinostomus spp. & 9 & 53.87 & 75.67 & $61-82$ & $\mathrm{ZB}$ & $\mathrm{T}$ & $\mathrm{D}$ & \\
\hline Bathygobius soporator ${ }^{2}$ & 6 & 147.96 & 115.5 & $101-143$ & $\mathrm{ZB}$ & $\mathrm{R}$ & $\mathrm{D}$ & Yes \\
\hline $\begin{array}{l}\text { Gobionellus oceanicus }^{2} \\
\text { Haemulidae }\end{array}$ & 2 & 36.48 & 158 & $158-158$ & $\mathrm{ZB}$ & $\mathrm{R}$ & $\mathrm{D}$ & Yes \\
\hline $\begin{array}{l}\text { Orthopristis ruber }{ }^{2} \\
\text { Mugilidae }\end{array}$ & 1 & 19.77 & 105 & 105 & $\mathrm{ZB}$ & $\mathrm{T}$ & $\mathrm{D}$ & Yes \\
\hline Mugil curema ${ }^{2}$ & 156 & 2065.3 & 103.68 & $73-143$ & DV & $\mathrm{T}$ & $\mathrm{D}$ & Yes \\
\hline Mugil gaimardianus & 97 & 754.21 & 93.35 & $61-116$ & DV & $\mathrm{T}$ & $\mathrm{D}$ & Yes \\
\hline Mugil liza ${ }^{1} \dagger \dagger$ & 293 & 19539 & 171.69 & $37-353$ & DV & $\mathrm{T}$ & $\mathrm{D}$ & Yes \\
\hline $\begin{array}{l}\text { Mugil spp. } \\
\text { Ophichthidae }\end{array}$ & 5 & 1.52 & 30 & $27-33$ & DV & $\mathrm{T}$ & $\mathrm{D}$ & \\
\hline $\begin{array}{l}\text { Ophichthus gomesii } \\
\text { Paralichthyidae }\end{array}$ & 1 & 92.25 & 455 & 455 & & $\mathrm{~T}$ & $\mathrm{D}$ & Yes \\
\hline Citharichthys arenaceus ${ }^{2}$ & 2 & 13.97 & 94.5 & 93-96 & $\mathrm{ZB}$ & $\mathrm{R}$ & $\mathrm{D}$ & Yes \\
\hline Citharichthys spilopterus $^{2}$ & 8 & 80.86 & 90.13 & $49-143$ & ZB & $\mathrm{R}$ & $\mathrm{D}$ & Yes \\
\hline
\end{tabular}


Continuation

\begin{tabular}{|c|c|c|c|c|c|c|c|c|}
\hline Families/Species & $\mathrm{n}$ & $\begin{array}{l}\mathrm{W} \\
(\mathrm{g})\end{array}$ & $\begin{array}{c}\text { Mean TL } \\
(\mathrm{mm})\end{array}$ & $\begin{array}{c}\text { Min-Max TL } \\
(\mathrm{mm})\end{array}$ & TG & GU & DP & $\begin{array}{l}\text { Economic } \\
\text { importance }\end{array}$ \\
\hline \multicolumn{9}{|l|}{ Poeciliidae } \\
\hline Poecilia sp. & 2 & 2.59 & 44 & $37-51$ & & $\mathrm{~T}$ & $\mathrm{BP}$ & \\
\hline Pomatomidae & 84 & 0210 & O & $70 \quad 150$ & DV & & & Y \\
\hline \multicolumn{9}{|l|}{ Sciaenidae } \\
\hline Bairdiella rhonchus ${ }^{2}$ & 2 & 32.01 & 107 & $104-110$ & $\mathrm{ZB}$ & $\mathrm{R}$ & $\mathrm{D}$ & Yes \\
\hline Cynoscion jamaicensis $^{2}$ & 3 & 28.81 & 88.67 & $69-126$ & $\mathrm{ZB}$ & $\mathrm{T}$ & $\mathrm{D}$ & Yes \\
\hline Cynoscion leiarchus ${ }^{2}$ & 28 & 1085.8 & 141.11 & $67-206$ & PV & $\mathrm{T}$ & $\mathrm{D}$ & Yes \\
\hline Micropogonias furnieri ${ }^{2} \dagger \dagger$ & 84 & 1881.9 & 123.68 & $49-193$ & $\mathrm{ZB}$ & $\mathrm{T}$ & $\mathrm{D}$ & Yes \\
\hline \multicolumn{9}{|l|}{ Tetraodontidae } \\
\hline Sphoeroides testudineus ${ }^{2}$ & 45 & 855.74 & 80.18 & $40-231$ & $\mathrm{ZB}$ & $\mathrm{R}$ & $\mathrm{D}$ & Not \\
\hline Total & 3883 & 44903 & & & & & & \\
\hline
\end{tabular}

Table 2. Results of Permanova based on the Bray-Curtis similarity of abundance (square-root transformed). Factors, Es: season, A: area, Res: residual, df: degrees of freedom, MS: mean square sum.

\begin{tabular}{lrccc}
\hline $\begin{array}{l}\text { Source of } \\
\text { variation }\end{array}$ & df & MS & Pseudo- $F$ & $P($ perm $)$ \\
\hline Es & 3 & 5825.5 & 2.5567 & 0.0003 \\
A & 4 & 9152.8 & 4.017 & 0.0001 \\
Es x A & 12 & 2612.7 & 1.147 & 0.183 \\
Res & 39 & 2278.5 & & \\
\hline
\end{tabular}

Table 3. Results of pairwise Permanova based on the BrayCurtis similarity of abundance (square-root transformed) between seasons, with values of the Student's $t$-test and permutation $P$-value $(P($ perm $))$.

\begin{tabular}{lll}
\hline Groups & \multicolumn{1}{c}{$t$} & $P($ perm $)$ \\
\hline Summer, Fall & 1.331 & 0.0862 \\
Summer, Winter & 1.7503 & $0.0029 * *$ \\
Summer, Spring & 1.188 & 0.2005 \\
Fall, Winter & 1.9676 & $0.0007 * * *$ \\
Fall, Spring & 1.7595 & $0.0059^{* *}$ \\
Winter, Spring & 1.4703 & $0.0331^{*}$ \\
\hline$P<0.05^{*} ; P<0.01^{* * ;} P<0.001^{* * *}$ \\
\hline
\end{tabular}

minance of $M$. curema, Harengula clupeola, and $E$. gula in the fall and winter were responsible for the observed separation of the groups (Fig. 3).

In relation to the areas, three clusters were observed in CAP: a group of the samples taken in areas 1,2 and 3 at the top of the graph; a cluster with samples from area 4 at the bottom and leftmost of the graph and a cluster to the right of the samples collected in area 5 (Fig. 4). High abundances of $G$. genidens and $M$. curema in areas 1,2 and 3, of C. edentulus in area 4 and Geophagus brasiliensis in area 5 were responsible for the clusters observed (Fig. 4).
Table 4. Results of pairwise Permanova based on the BrayCurtis similarity of abundance (square-root transformed) between sampling areas, with values of the Student's $t$-test and permutation $P$-value $(P($ perm $))$.

\begin{tabular}{ccl}
\hline Groups & $t$ & $P($ perm $)$ \\
\hline 1,2 & 1.0479 & 0.3545 \\
1,3 & 1.3609 & 0.0797 \\
1,4 & 2.2927 & $0.0002^{* * *}$ \\
1,5 & 2.0918 & 0.0022 \\
2,3 & 1.1945 & 0.1656 \\
2,4 & 1.971 & $0.0007^{* * *}$ \\
2,5 & 2.0733 & $0.0011^{* *}$ \\
3,4 & 1.9928 & $0.0042^{* *}$ \\
3,5 & 2.4039 & $0.0002^{* * *}$ \\
4,5 & 3.0215 & $0.0001^{* * *}$ \\
\hline$P<0.05^{*} ; P<0.01^{* *} ; P<0.001^{* * *}$ \\
\hline \multicolumn{4}{l}{}
\end{tabular}

\section{DISCUSSION}

The analytical approach used in the present study is unprecedented for the Itacorubi mangrove. A previous survey was done with similar results (Soriano-Sierra et al., 1998). However, spatial and temporal assemblage patterns were not evaluated. Despite the dominance of a few species, which is a remarkable feature in lagoon and estuarine environments due to significant changes in physical and chemical variables (Day et al., 1989), there are differences in abundance between seasons and areas, commonly present in other surveys conducted in shallow areas (Spach et al., 2010; Contente et al., 2011; Vilar et al., 2011; Souza-Conceição et al., 2013; Cartagena et al., 2014; Ribeiro et al., 2014; Soeth et al., 2015; Cattani et al., 2016a). The use of such environments by juveniles, generally zoobenthivorous, is characterized by the availability of food associated with the substrate. According to Whitfield \& Elliott (2002), shallow areas, beaches and mangroves are of 


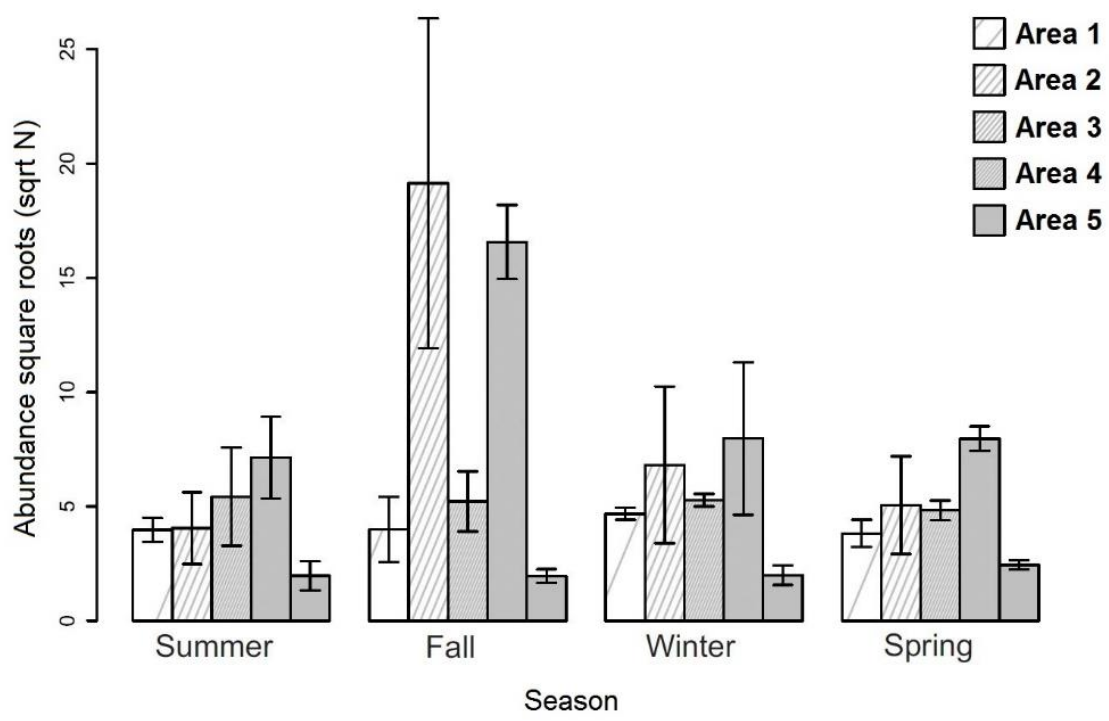

Figure 2. Mean values (standard error in the bars) of the abundance square root of fish caught in the four seasons of the year and areas 1, 2, 3, 4 and 5 in 1988 in the Itacorubi mangrove, Santa Catarina Island.

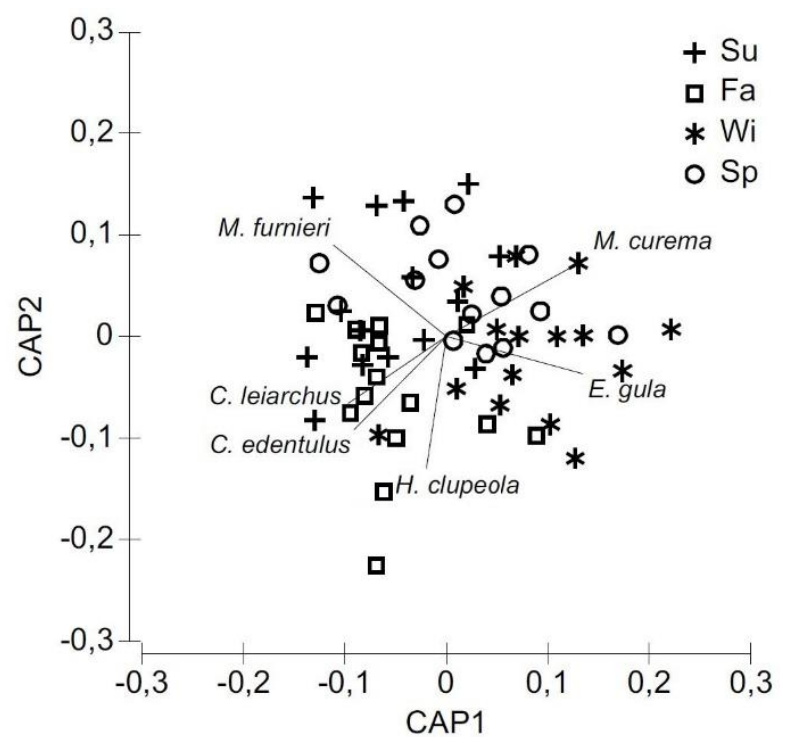

Figure 3. Result of the canonical analysis of principal coordinates (CAP), with the species that contributed to the differences between the seasons. Vectors of species elaborated based on the Spearman correlation with the index above $0.5(P>0.5)$. The canonical correlation of the axes obtained by the analysis was $\delta 1=0.6587$ and $\delta 2=$ 0.5674. Su: summer, Fa: fall, Wi: winter and Sp: spring.

extreme importance for juvenile fish and other aquatic organisms.

As a general framework, fish assemblage structure is influenced by a combined set of environmental variables, which provides a suitable habitat, and by other biological variables such as predator-prey interactions and inter- and intra-specific competition (Whitfield

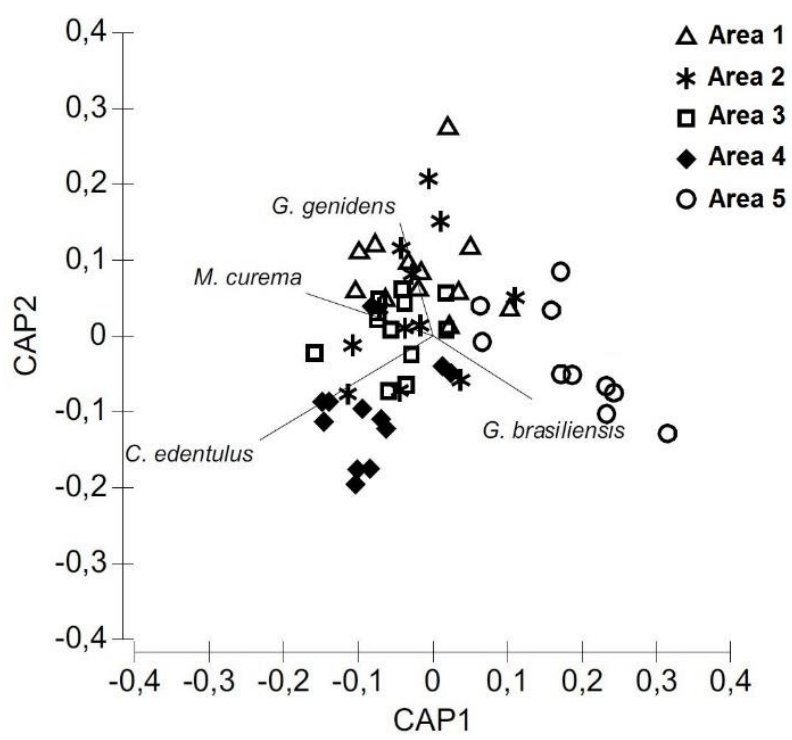

Figure 4. Result of the canonical analysis of principal coordinates (CAP), with the species that contributed to the differences between the areas. Vectors of species elaborated based on the Spearman correlation with the index above $0.5(P>0.5)$. The canonical correlation of the axes obtained by the analysis was $\delta 1=0.8487$ and $\delta 2=$ 0.7044 .

\& Elliott, 2002). The higher abundances observed mainly in the fall could be explained by the nutrient input caused by highly rainfall, typical at this time of year. These patterns were also observed in nearby areas in the western margin of Santa Catarina Island (Cartagena et al., 2014; Ribeiro et al., 2014; Soeth et al., 2015; Cattani et al., 2016a,b). 
Concerning the most abundant species, there was a high occurrence of Cetengraulis edentulus and Mugil liza, representing more than $70 \%$ of the individuals caught. This pattern, with emphasis on the occurrence of the genera Mugil and Cetengraulis, has also been observed in other studies in shallow areas (SouzaConceição et al., 2013; Cartagena et al., 2014; Borgo et al., 2015; Cattani et al., 2016b).

Considering the high abundance of $C$. edentulus individuals caught in the summer and spring and at site 4 , we can infer that these individuals may be hiding from predators and establishing their temporary niches for growth in these environments due to they are present in the Itacorubi River, an area with less influence of the tide, and because they are considered transient in the estuary. This assumption is in agreement with the breeding pattern of the species (Franco et al., 2014), which presents an extended reproductive period between late winter and spring, with more intense reproductive activity in November, entering the estuaries in the following months. A similar pattern occurred in the shallow areas of the Sepetiba Bay (Pesanha \& Araujo, 2003) and a tidal river in the Pinheiros Bay (Oliveira-Neto et al., 2010). In the life cycle of most species of engraulids, there is a characteristic phase that occurs in more sheltered coastal areas, such as bays and lagoons (Blaxter \& Hunter, 1982), where they seek protection against predators (Oliveira-Neto et al., 2010), such as Pomatomus saltatrix, a top-chain predator fish species that use estuarine areas for feeding (Froese \& Pauly, 2017), present in a significant number in Itacorubi.

The presence of $P$. saltatrix, classified as vulnerable by the red list of endangered species, was representative in Itacorubi and was also present in the works carried out in a mangrove with similar characteristics in the northern bay of Florianópolis (Cattani et al., 2016b), in the Saco dos Limões region, in the southern bay of Florianópolis (Cartagena et al., 2014) and in the Conceição Lagoon in Florianópolis (Borgo et al., 2015). Besides that, the presence was also observed in the Paranaguá Estuary, State of Paraná, especially at beaches (Felix et al., 2002), tidal rivers (Vendel et al., 2002; Spach et al., 2004b) and tidal plains (Santos et al., 2002; Spach et al., 2004a) near the entrances of the estuary, but was absent in most surveys performed in the more internal shallow areas of this estuary (Falcão et al., 2006; Hackradt et al., 2009; Pichler et al., 2015). The absence of this species was also verified in shallow areas of the Babitonga Bay (Vilar et al., 2011; SouzaConceição et al., 2013) and five estuaries of Rio Grande do Sul (Ramos \& Vieira, 2001). Thus, the occurrence of this vulnerable species reinforces the importance of mangrove conservation.
The second most abundant species, M. liza, occurred predominantly in the winter, it is a species that performs reproductive migration from the coast of Argentina to the Brazilian southeast coast from April to June, with a spawning peak between the northern coast of Santa Catarina and Paraná (Lemos et al., 2014). The highest abundances observed in the winter in the Itacorubi and other studies on the fish fauna (IBAMA, 1994; Spach et al., 2000; Ramos \& Vieira, 2001; Ignácio \& Spach, 2009; Contente et al., 2011) reflects the migratory and reproductive pattern described for this species.

However, the alternating peaks of abundance between M. liza and M. curema are recurrent. While in the spring and summer, there is a peak of M. curema and a low occurrence of $M$. liza, in the fall and winter, the pattern reverses. As in the Itacorubi mangrove, this pattern of alternating occurrence of $M$. liza and $M$. curema was also registered in the Camboriú River (IBAMA, 1994), in the northern bay of Florianópolis (Cattani et al., 2016a), in the mangrove of the Ratones River (Cattani et al., 2016a) and in shallow areas of the State of Rio Grande do Sul: Arroio Chuí estuary, Patos Lagoon estuary, Peixe Lagoon estuary, TramandaíArmazém Lagoon Complex and Mampituba River estuary (Ramos \& Vieira, 2001).

The catfish Genidens genidens was among the most abundant in the present study, as also reported for the Ratones River estuary (Cattani et al., 2016a) and demersal areas of the northern bay (Cattani et al., 2016a) and Saco dos Limões on the southern bay (Cartagena et al., 2014), and to a lesser extent in relation to the total catch in the Conceição Lagoon (Borgo et al., 2015) and Indio Beach (Ribeiro et al., 2014; Soeth et al., 2015).

The presence of Genidens barbus in the Itacorubi mangrove was also verified in the estuarine (Cattani et al., 2016b), beach (Ribeiro et al., 2014; Soeth et al., 2015) and demersal environments of the northern (Cattani et al., 2016a) and southern (Cartagena et al., 2014) bays of Florianópolis, but not in samples from the Conceição Lagoon (Borgo et al., 2015). This same pattern of occurrence in different environments near the estuary of the Itacorubi mangrove was also observed in Micropogonias furnieri (Cartagena et al., 2014; Ribeiro et al., 2014; Soeth et al., 2015; Cattani et al., 2016a,b) but in this case, the species was captured in the Conceição Lagoon (Borgo et al., 2015).

In addition to the mentioned species, such as in the Itacorubi River estuary, occurred at the Índio Beach (Ribeiro et al., 2014; Soeth et al., 2015), Conceição Lagoon (Borgo et al., 2015), Ratones River estuary (Cattani et al., 2016b), and in the northern (Cattani et al., 2016a) and southern (Cartagena et al., 2014) bays, 
all located on the Santa Catarina Island, the species Achirus lineatus, Centropomus parallelus, Citharichthys spilopterus, Cynoscion leiarchus, Diapterus rhombeus, Eucinostomus argenteus, E. gula, Gobionellus oceanicus, Harengula clupeola, Oligoplites saurus, Sphoeroides testudineus and Symphurus tessellatus.

In study research, we caught nine individuals of Geophagus brasiliensis, a freshwater species, which is expected, as this species was caught in the Sertão River (site 5, Fig. 1) where the marine influence should be reduced due to the low tidal amplitude in the estuary (Soriano-Sierra, 1997). In the Ratones Estuary, also on the shore of northern bay of the Santa Catarina Island, the catch of this species was even larger ( 35 specimens) at a more internal sampling point located in an area where the physical and chemical variations mainly respond to the continental contribution (Simonassi et al., 2010).

As far as the economic importance is concerned (Table 1), in the geographic distribution area of the species, 33 species are commercially used in fishing, aquaculture or aquaria, and for four, there is no economic interest (Froese \& Pauly, 2017). Most of the fish fauna of the Itacorubi River estuary was evaluated according to conservation status (Table 1). Thirty-three are on the red list of the Union for Conservation of Nature and Natural Resources - IUCN (IUCN, 2019), where 30 are classified as least concern, G. genidens as endangered, M. liza as deficient data and P. saltatrix, as vulnerable. On the other hand, only four species of this estuary are evaluated according to the conservation status in the list of the Ministry of Environment - MMA (MMA, 2004b), with Sardinella brasiliensis exclusive of this list and classified as overexploited, G. genidens, least concern in the IUCN list and endangered in the MMA list, $M$. liza as deficient data in the IUCN list and overexploited in the MMA list and $P$. saltatrix, as vulnerable in IUCN and overexploited in MMA.

Finally, this study considered only the abundance of species at different sites of a micro estuary and showed the importance of seasonality in structuring fish assemblage, especially in the ecological niche structures. Thus, for a better understanding of these niches, we suggest studies with molecular tools focusing on key species to better interpret these patterns.

\section{REFERENCES}

Alongi, D.M. 2002. Present state and future of the world's mangrove forests. Environmental Conservation, 29(3): 331-349. doi: 10.1017/S0376892902000231

Anderson, M.J., Gorley, R.N. \& Clarke, K.R. 2008. Permanova+ for primer: guide to software and statistical methods. Primer-E, Plymouth.
Blaber, S.J.M. 2007. Mangroves and fishes: issues of diversity, dependence, and dogma. Bulletin of Marine Science, 80(3): 457-472.

Blaxter, J.H.S. \& Hunter, J.R. 1982. The biology of the clupeoid fishes. Advances in Marine Biology, 20: 1223. doi: 10.1016/S0065-2881(08)60140-6

Borgo, D., Cattani, A.P., Ribeiro, G.C., Pichler, H.A., Hostim-Silva, M., Clezar, L., Santos, L.O. \& Spach, H.L. 2015. Os padrões de distribuição dos peixes de uma laguna costeira aberta no Atlânctico oeste subtropical são influenciados pelas variações espaciais e sazonais? Revista Biotemas, 28(3): 93-105. doi: 10.5007/2175-7925.2015v28n3p93

Cartagena, B.F.C., Hostim-Silva, M. \& Spach, H.L. 2014. Composição e variação temporal da assembleia de peixes na Região do Saco dos Limões, Baía Sul, Florianópolis, Santa Catarina. Arquivos de Ciências do Mar, 47(2): 46-56. doi: 10.32360/acmar.v47i2. 5932

Cattani, A.P., Jorge, F.G.D., Ribeiro, G.C., Wedekin, L.L., Lopes, P.C.A.S., Rupil, G.M. \& Spach, H.L. 2016a. Fish assemblages in a coastal bay adjacent to a network of marine protected areas in southern Brazil. Brazilian Journal of Oceanography, 64(3): 295-308. doi: 10.1590/S1679-8759201 6121306403

Cattani, A.P., Ribeiro, G.C., Marcon, E., Soeth, M., Hostim-Silva, M., Clezar, L. \& Spach, H.L. 2016 b. Fish assemblage dynamics in the Ratones River Mangrove, State of Santa Catarina, Brazil. PanAmerican Journal of Aquatic Sciences, 11(4): 324335.

Contente, R.F., Stefanoni, M.F. \& Spach, H.L. 2011. Fish assemblage structure in an estuary of the Atlantic Forest biodiversity hotspot (southern Brazil). Ichthyological Research, 58(1): 38-50. doi: 10.1007/s10228010-0192-0

Cyrus, D.P. \& Blaber, S.J.M. 1987. The influence of turbidity on juvenile marine fish in the estuaries of Natal, South Africa. Continental Shelf Research, 7(1112): 1411-1416. doi: 10.1016/0278-4343(87) 90046-X

Dahdouh-Guebas, F., Jayatissa, L.P., Di Nitto, D., Bosire, J.O., Lo Seen, D. \& Koedam, N. 2005. How effective were mangroves as a defense against the recent tsunami? Current Biology, 15(12): 443-447. doi: 10.1016/j.cub.2005.06.008

Day Jr., J.W., Hall, C.A.S., Kemp, W.M. \& YañezArancibia, A. 1989. Estuarine ecology. John Wiley and Sons, New York.

Duke, N.C., Meyneckes, J.O., Dittmann, S., Ellison, A.M., Anger, K., Beger, A., Cannicci, S., Diele, K., Ewel, K.C., Field, C.D., Koedam, N.S., Lee, Y., Marchand, C., Nordhaus, I. \& Dahdouh-Guebas, F. 2007. A world without mangroves? Science, 317(5834): 41-42. doi: 10.1126/science.317.5834.41b 
Dutra, S.J. 1998. A bacia hidrográfica do Córrego-Grande, Ilha de Santa Catarina, Brasil. In: Soriano-Sierra, E.J. \& Sierra de Ledo, B. (Eds.). Ecologia e gerenciamento do Manguezal do Itacorubi. NEMAR/CCB/UFSC, SDM/FEPEMA, Florianópolis, pp. 31-46.

Elliott, M. \& Mclusky, D.S. 2002. The need for definitions in understanding estuaries. Estuarine, Coastal and Shelf Science, 55(6): 815-827. doi: 10.1006/ecss. 2002.1031

Ellis, W.L. \& Bell, S.S. 2004. Conditional use of mangrove habitats by fishes: depth as a cue to avoid predators. Estuaries, 27(6): 966-976. doi: 10.1007/BF0 2803423

Falcão, M.G., Sarpedonti, V., Spach, H.L., Otero, M.E.B., Queiroz, G.M.L.N. \& Santos, C.A. 2006. Ictiofauna em planícies de maré das Baías das Laranjeiras e de Paranaguá, Paraná, Brasil. Revista Brasileira de Zoociências, 8(2): 125-138.

Faunce, C.H. \& Serafy, J.E. 2006. Mangroves as fish habitat: 50 years of field studies. Marine Ecology Progress Series, 318: 1-18. doi: 10.3354/meps318001

Felix, F.C., Spach, H.L., Moro, P.S., Hackradt, C.W., Queiroz, G.M.L.N. \& Hostim-Silva, M. 2002. Ichthyofauna composition across a wave - energy gradient on southern Brazil beaches. Brazilian Journal of Oceanography, 55(4): 281-292. doi: 10.1590/ S1679-87592007000400005

Franco, A.C.S., Brotto, D.S., Zee, D.M.W. \& Santos, L.N. 2014. Reproductive biology of Cetengraulis edentulus (Cuvier, 1829), the major fishery resource in Guanabara Bay, Brazil. Neotropical Ichthyology, 12(4): 819-826. doi: 10.1590/1982-0224-20130205

Froese, R. \& Pauly, D. 2017. FishBase. World Wide Web electronic publication. Version (07/2013). [http:// www.fishbase.org/home.htm]. Reviewed: July 20, 2018.

Guilstrom, M., Bodin, M., Nilsson, P.G. \& Ohman, M.C. 2008. Seagrass structural complexity and landscape configuration as determinants of tropical fish assemblage composition. Marine Ecology Progress Series, 363: 241-255. doi: 10.3354/meps07427

Hackradt, C.W., Pichler, H.A., Felix, F., Schwarz-Junior, R., Silva, L.O. \& Spach, H.L. 2009. A estrutura da comunidade de peixes em praias de baixa energia do Complexo Estuarino da Baía de Paranaguá, Brasil. Revista Brasileira de Zoociências, 11(3): 231-242.

Hussan, S.A. \& Bardola, R. 2008. Valuing mangrove ecosystem services: linking nutrient retention function of mangrove forests to enhanced agroecosystem production. Wetlands Ecology and Management, 16(6): 441-450. doi: 10.1007/s11273-008-9080-Z

Huxham, M., Kimani, E. \& Augley, J. 2004. Mangrove fish: a comparison of community structure between forested and cleared habitats. Estuarine, Coastal and
Shelf Science, 60(4): 637-647. doi: 10.1016/ j.ecss. 2004.03.003

Ignácio, J.M. \& Spach, H.L. 2009. Variação entre o dia e a noite nas características da ictiofauna do infra-litoral raso do Maciel, Baía de Paranaguá, PR. Revista Brasileira de Zoociências, 11: 25-37.

Instituto Brasileiro do Meio Ambiente e Recursos Naturais Renováveis (IBAMA). 1994. Manguezal do Rio Camboriú: preservação e controle da qualidade ambiental. Coleção Meio Ambiente, Série EstudosPesca, 13, Itajaí.

International Union for Conservation of Nature (IUCN). 2019. The IUCN red list of threatened species. IUCN Global Species Programme Red List Unit. [http:// www.iucnredlist.org]. Reviewed: September 6, 2019.

Kathiresan, K. \& Bingham, B.L. 2001. Biology of mangroves and mangrove ecosystems. Avanços na Biologia Marinha, 40: 81-251. doi: 10.1016/S00652881(01)40003-4

Laegdsgaard, P. \& Johnson, C.R. 2001. Why do juvenile fish utilize mangrove habitats? Journal of Experimental Marine Biology and Ecology, 257(2): 229-253. doi: 10.1016/S0022-0981(00)00331-2

Lemos, V.M., Junior-Varela, A.S, Schwingel, P.R., Muelbert, J.H. \& Vieira, J.P. 2014. Migration and reproductive biology of Mugil liza (Teleostei: Mugilidae) in south Brazil. Journal of Fish Biology, 85(3): 671-687. doi: 10.1111/jfb.12452

Lugendo, B.R., de Groene, A., Cornelissen, I., Pronker, A., Nagelkerken, I., Dorenbosh, M., van der Velde, G. \& Mgaya, Y.D. 2007. Spatial and temporal variation in fish community structure of a marine embayment in Zanzibar, Tanzania. Hydrobiologia, 586(1): 1-16. doi: 10.1007/s10750-006-0398-3

Ministério do Meio Ambiente (MMA). 2004a. Informe Nacional sobre áreas protegidas do Brasil. MMA, Brasília. [http://www. https://www.mma.gov.br/estruturas/sbf2008_dap/_publicacao/149_publicacao16122 010110837.pdf]. Reviewed: November 29, 2019.

Ministério do Meio Ambiente (MMA). 2004b. Livro vermelho da fauna ameaçada no Estado do Paraná. Instituto Ambiental do Paraná. Brazilian Ministry of Environment. [http://www.meioambiente.pr.gov.br/ modules/conteudo/conteudo.php?conteudo=139]. Reviewed: November 29, 2019.

Nagelkerken, I. \& Faunce, C.H. 2007. Colonization of artificial mangroves by reef fishes in a marine seascape. Estuarine, Coastal and Shelf Science, 75(3): 417-422. doi: 10.1016/j.ecss.2007.05.030

Oliveira-Neto, J.F., Spach, H.L., Schwarz-Junior, R. \& Pichler, H.A. 2010. Fish communities of two tidal creeks in the Pinheiros Bay, State of Paraná, southern 
Brazil. Brazilian Journal of Aquatic Science and Technology, 14(2): 47-54. doi: 10.14210/bjast.v14n2. p47-54

Panitz, C.M.N. 1986. Produção e decomposição de serrapilheira no Mangue do Rio Itacorubi, Ilha de

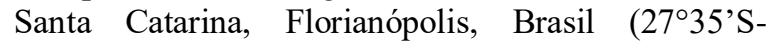
$48^{\circ} 31^{\prime}$ W). Tese de Doutoramento, Depto. de Ciências Biológicas da UFSCar, São Carlos.

Passos, A.C., Contente, R.F., Abbatepaulo, F.V., Spach, H.L., Vilar, C.C., Joyeux, J.C., Cartagena, B.F.C. \& Fávaro, L.F. 2013. Analysis of fish assemblages in sectors along a salinity gradient based on species, families, and functional groups. Brazilian Journal of Oceanography, 61(4): 251-264. doi: 10.1590/S167987592013000400006

Pesanha, A.L.M. \& Araujo, F.G. 2003. Spatial, temporal, and diel variations of fish assemblages at two sandy beaches in the Sepetiba Bay, Rio de Janeiro, Brazil. Estuarine, Coastal and Shelf Science, 57(5-6): 817828. doi: 10.1016/S0272-7714(02)00411-0

Pichler, H.A., Spach, H.L., Gray, C.A., Broadhurst, M.K., Schwarz-Junior, R. \& Neto, J.F.O. 2015. Environmental influences on resident and transient fishes across shallow estuarine beaches and tidal flats in a Brazilian World Heritage area. Estuarine, Coastal, and Shelf Science, 164: 482-492. doi: 10.1016/j.ecss. 2015.07.041

Pittman, S.J., McAlpine, C.A. \& Pittman, K.M. 2004. Linking fish and prawns to their environment: a hierarchical landscape approach. Marine Ecology Progress Series, 283: 233-254. doi: 10.3354/meps 283233

Ramos, L.A. \& Vieira, J.P. 2001. Composição específica e abundância de peixes de zonas rasas dos cinco estuários do Rio Grande do Sul, Brasil. Boletim do Instituto de Pesca, 27(1): 109-121.

Ribeiro, G.C., Soeth, M., Andrade, V.K., Spach, H.L. \& Cattani, A.P. 2014. Nycthemeral and monthly occupation of the fish assemblage on a sheltered beach of Baía Norte, Florianópolis, Santa Catarina State, Brazil. Brazilian Journal of Oceanography, 62(2): 209223. doi: $10.1590 /$ S1679-87592014065606203

Rönnbäck, P., Troell, M., Kautsky, N. \& Primavera, J.H. 1999. Distribution pattern of shrimps and fish among Avicennia and Rhizophora microhabitats in the Pagbilao Mangroves, Philippines. Estuarine, Coastal and Shelf Science, 48(2): 223-234. doi: 10.1006/ ecss.1998.0415

Rypel, A.L., Layman, C.A. \& Arrington, D.A. 2007. Water depth modifies relative predation risk for a motile fish taxon in Bahamanian tidal creeks. Estuaries and Coasts, 30(3): 518-525. doi: 10.1007/BF03036 517

Simonassi, J.C., Hennemann, M.C., Talgatti, D. \& Marques-Junior, A.N. 2010. Nutrient variations and coastal water quality of Santa Catarina Island, Brazil. Biotemas, 23(1): 211-223.

Soeth, M., Ribeiro, G.C., Spach, H.L., Cattani, A.P. \& Andrade, V.K. 2015. Comparison of the temporal and taxonomic patterns of ichthyofauna captured with a fyke net in two sheltered environments in southern Brazil. Latin American Journal of Aquatic Research, 43(1): 107-122. doi: 10.3856/vol43-issue1-fulltext-10

Soriano-Sierra, E.J. 1993. Caracterização ecológica dos biótopos e sua ocupação pelas comunidades vegetais no manguezal do Itacorubi (Ilha de Santa Catarina, SC, Brasil). Trabalho do concurso público para professor adjunto da Universidade Federal de Santa Catarina, Florianópolis.

Soriano-Sierra, E.J. 1997. Fluxos de maré e interferência antropogênica a hidrodinâmica, no interior de um manguezal naturalmente estressado. Estudo de caso. Aquitaine Océan, 1(3): 163-178.

Soriano-Sierra, E.J., Silva, J.R.B.M., Derner, R.B. \& Branco, J.O. 1998. Aspectos ecológicos do Manguezal de Itacorubi, Santa Catarina, Brasil. Ecologia e Gerenciamento do Manguezal do Itacorubi. Série Fepema, 3: 115-138.

Souza-Conceição, J.M., Spach, H.L., Bordin, D., Frisanco, D. \& Costa, M.D.P. 2013. The role of estuarine beaches as habitats for fishes in a Brazilian subtropical environment. Neotropical Biology and Conservation, 8(3): 121-131.

Spach, H.L., Santos, C. \& Godefroid, R.S. 2000. Padrões temporais na assembleia de peixes na gamboa do Sucuriú, Baia de Paranaguá, Brasil. Revista Brasileira de Zoologia, 20(4): 591-600. doi: 10.1590/S010181752003000400005

Spach, H.L., Godefroid, R.S., Santos, C., Schwarz-Junior, R. \& Queiroz, G.M.L. 2004a. Temporal variation in fish assemblage composition on a tidal flat. Brazilian Journal of Oceanography, 52(1): 47-58. doi: 10.1590/ S1679-87592004000100005

Spach, H.L., Santos, C., Godefroid, R.S., Nardi, M. \& Cunha, F. 2004b. A study of the fish community structure in a tidal creek. Brazilian Journal of Biology, 64(2): 1-15. doi: 10.1590/S1519-69842004000200 020

Spach, H.L., Silva, A.L.C., Bertolli, L., Cattani, A.P., Budel, B.R. \& Santos, L.O. 2010. Assembléias de peixes em diferentes ambientes da desembocadura do rio Saí Guaçu, sul do Brasil. Pan-American Journal of Aquatic Sciences, 5(1): 126-138.

Valiela, I., Bowen, J.L. \& York, J.K. 2001. Mangrove forests: one of the world's threatened major tropical environments. BioScience, 51: 807-815. doi: 10.1641/ 0006-3568(2001)051[0807:MFOOTW]2.0.CO;2 
Vendel, A.L., Spach, H.L., Lopes, S.G. \& Santos, C. 2002. Structure and dynamics of fish assemblage in a tidal creek environment. Brazilian Archives of Biology and Technology, 45(3): 365-373. doi: 10.1590/S151689132002000300015

Verweij, M.C., Gelkerken, I., Graaff, D., Peeters, M., Bakker, E.J. \& Van der Velde, G. 2006. Structure, food, and shade attract juvenile coral reef fish to mangrove and seagrass habitats: a field experiment. Marine Ecology Progress Series, 306: 257-268. doi: 10.3354/meps306257

Received: 10 May 2018; Accepted: 15 September 2019
Vilar, C.C., Spach, H.L. \& Joyeux, J.C. 2011. Spatial and temporal changes in the fish assemblage of a subtropical estuary in Brazil: environmental effects. Journal of the Marine Biological Association of the United Kingdom, 91(3): 635-648. doi: 10.1017/S002 5315410001943

Whitfield, A.K. \& Elliott, M. 2002. Fishes as indicators of environment and ecological changes within estuaries: a review of progress and some suggestions for the future. Journal of Fish Biology, 61: 229-250. doi: 10.1111/j.1095-8649.2002.tb01773.x

Williamson, I., King, C. \& Mather, P.B. 1994. A comparison of fish communities in unmodified and modified inshore habitats of Raby Bay, Queensland. Estuarine, Coastal and Shelf Science, 39(4): 401-411. doi: $10.1006 /$ ecss. 1994.1072 